\title{
M-learning ve výuce ekonomického jazyka: Jak využít smartphone k rovnoměrnému rozvoji všech řečových dovedností
}

\author{
M-learning in the process of teaching foreign business language: \\ How to develop all language skills evenly by using smartphone
}

\author{
Lenka Kalousková
}

\begin{abstract}
Abstrakt: Článek se zabývá současnými aspekty výuky cizího ekonomického jazyka v oblasti terciárního vzdělávání se zřetelem na nové digitální technologie, které přinášejí zcela novou dimenzi do koncepce jazykové výuky na vysokých školách. Díky rozsáhlému používání mobilních zařízení jako jsou smartphony a tablety se stal m-learning účinným nástrojem při prezenční fázi výuky i v rámci ř́zeného samostudia. Cílem této práce je ukázat, jak lze pomoci m-learningu rovnoměrně rozvíjet a podporovat individuální řečové dovednosti. Na závěr je jako ilustrativní příklad připojen konkrétní scénář použití m-learningu v rámci tzv. hybridního konceptu výuky.
\end{abstract}

Klíčová slova: odborný cizí jazyk, hybridní koncept výuky, m-learning, terciární vzdělávání

\begin{abstract}
This article deals with current aspects of teaching foreign business languages for specific purposes in tertiary education, with reference to new digital technologies, which bring completely new dimensions into the output of the foreign languages learning concept at universities. The widespread use of mobile devices such as smartphones and tablets, especially in young population, allows m-learning to become an effective tool in teaching and learning inside and outside the classroom. The aim of this paper is to show how m-learning can support and develop individual foreign language competences and skills evenly. Finally, a concrete media-supported learning scenario is presented as an illustrative example of the so-called hybrid learning concept.
\end{abstract}

Key words: foreign language for specific purposes, hybrid learning concept, m-learning, tertiary education

\section{Úvod}

Rychlý rozvoj informačních a komunikačních technologií zvyšuje digitální gramotnost mladé generace a mění nároky na volbu a implementaci nových forem výuky do edukačního procesu. Z výsledků průzkumu společnosti ESET a Seznam.cz zveřejněných v říjnu 2018 vyplývá, že již ve školním roce 2018/19 disponovalo 96 \% českých žáků a studentů vlastním smartphonem ${ }^{1}$. Masové rozšíření mobil-

\footnotetext{
${ }^{1}$ https://www.mobilmania.cz/clanky/smartphone-pouziva-96-ceskych-studentu-chrani-jej-vsakmene-nez-polovina/sc-3-a-1343136/default.aspx Stav k 1. 2. 2019
} 
ních komunikačních technologií potvrzují i zkušenosti z pedagogické praxe v oblasti terciárního vzdělávání. Pro dnešní posluchače vysokých škol je smartphone či tablet neodmyslitelnou součástí každodenního života. Logicky se tak nabízí otázka, jak efektivně integrovat používání přenosných mobilních přístrojů do vzdělávacího procesu, konkrétně do výuky odborného cizího jazyka, vyučovaného v akademickém prostředí. Cílem tohoto příspěvku je ukázat, že se využití smartphonu při výuce odborného cizího jazyka nemusí omezovat pouze na nástroje a aplikace vhodné pro osvojování slovní zásoby a procvičování gramatiky, ale že díky m-learningu lze rovnoměrně rozvíjet všechny jednotlivé produktivní a receptivní dovednosti, a to jak během prezenční fáze studia, tak během řízeného samostudia.

\section{M-learning a jeho výhody}

Učitelé cizích jazyků jsou stále častěji konfrontováni s implementací nových lingvodidaktických metod, které se opírají o využívání různých forem e-learningu a nově zejména m-learningu. Pojmem m-learning označujeme vzdělávání pomocí mobilních aplikací a technologií. Je to forma výuky, která integruje některé z přenosných zařízení jako smartphone, tablet, notebook apod. a snaží se využít jejich potenciál: autentičnost, aktuálnost, situativní zakotvenost, vzájemnou propojenost, audiovizuální aspekty atd. Přitom je třeba poukazovat také na negativní jevy spojené s m-learningem a pokusit se je eliminovat. Kromě nomofobie k nim patř́ zejména rozptylování pozornosti nejrůznějšími funkcemi mobilního zařízení, omezování vlastní myšlenkové aktivity, logického odhadu a schopnosti kompenzační strategie. Nespornou výhodou m-learningu je celá řada interaktivních výukových programů a aplikací, studující na vysokých školách ocení př́stup k neomezenému množství aktuálních autentických materiálů a možnost vzájemné konektivity. Ta se osvědčuje především při používání elektronických autorských nástrojů platformy Web 2.0, kde uživatelé díky softwarovým aplikacím sami generují a sdílejí obsah (audiovizuální materiály, texty, gramatická a lexikální cvičení). Další významnou předností m-learningu je prostorová i časová flexibilita při učení a okamžitý přístup k informacím. Navíc není na rozdíl od nižších stupňů vzdělávacích zařízení využívání mobilních přístrojů v akademickém prostředí nijak reglementováno.

Ignorování digitálních technologií ve výuce cizího jazyka by bylo popíráním reality. O rozsahu využívání digitálních př́strojů a mobilních aplikací se však mezi pedagogy vedou kontroverzní debaty. Jako př́klad uvedeme závěr výzkumu profesora Johna Hattie, který na základě meta-analýzy tisíců celosvětově provedených studií stanovil indikátory účinnosti různých výukových metod, zvláštní pozornost přitom věnoval roli technologií. Podle studie, kterou Hattie zveřejnil pod názvem Visible Learning (2009), zůstávají učební efekty pomocí digitálních médií lehce podprůměrné, za nejúčinnější faktor při osvojování obsahu učiva ve výuce je považován vztah vyučující-žák (Hattie, 2009, s. 72). Vzhledem k absenci důkazů však není 
možné určit, jak dalece lze výsledky studie Hattie aplikovat na výuku cizího jazyka v terciární sféře.

Po technické stránce je předpokladem pro plošné využití m-learningu ve výuce na vysokých školách disponování vlastním mobilním přístrojem, který si studující do výuky přinesou. Pro toto aranžmá se vžilo označení zkratkou BYOD z ang. bring your own device „přines si vlastní přístroj“ (Brunner, 2014, s. 29-30). Neomezený přístup na internet je $\mathrm{v}$ akademickém prostředí zajištěn bezplatným připojením do sítě Eduroam (zkratka pro Education Roaming). Protože hodinové dotace pro výuku cizího jazyka jsou na vysokých školách obecně nízké, uplatňuje se obvykle hybridní koncept výuky s vyšším podílem řízeného samostudia. Právě v tomto ohledu je m-learning ideálním nástrojem, mimo jiné také proto, že umožňuje individuální studijní tempo.

Na stránkách European Centre for Modern Languages of the Council of Europe ${ }^{2}$ nalezneme rozsáhlý seznam online nástrojů a otevřených vzdělávacích zdrojů vhodných pro výuku moderních cizích jazyků. Konkrétní nástroje a aplikace je zde možné vyhledávat podle procvičovaných kompetencí (poslech, mluvení, čtení, psaní, gramatika, slovní zásoba atd.) i podle základních funkcí (hry, překlad, sdílení audia či videa, myšlenkové mapy, vytváření př́iběhů apod.).

\section{Gramatika a slovní zásoba}

Vzhledem k povaze studia cizích jazyků ve vysokoškolském prostředí, které předpokládá velký podíl individuální výuky, představují online gramatická a lexikální cvičení vhodný nástroj k osvojování jazyka v rámci ř́zeného samostudia. Neodmyslitelným pomocníkem ve studiu cizího jazyka jsou jednojazyčné i dvojjazyčné online slovníky a mobilní aplikace zaměřené na upevňování gramatiky a slovní zásoby. Patří k nim např aplikace DuoLingo, určená k procvičování slovní zásoby a překladu vět v souladu s dosaženou jazykovou úrovní. Zakomponováním herních prvků motivuje k pravidelnému užívání. Aplikace Dril pracuje se slovní zásobou, kterou si do ní uživatel sám vloží a následně dostatečně dlouho memoruje. Webová aplikace Landigo posílá zaregistrovaným uživatelům denně nová cvičení s výběrovou odpovědí na bázi multiple choice. Na zvýšenou poptávku po m-learningu reaguje i řada nakladatelství, která doplňují tradiční tištěné učebnice elektronickou databází interaktivních cvičení (např. Hueber, Klett, Schubert, Oxford University Press aj.). Rostoucí popularitu m-learningu reflektují také zahraniční jazykové instituty, na jejichž webových stránkách je dostupné množství různorodých online cvičení a materiálů (Goethe Institut, British Council). Většina zmíněných poskytovatelů a konkrétních aplikací se však zaměřuje téměř výlučně na procvičování obecného jazyka, což neodpovídá požadavkům a potřebám výuky cizího jazyka

\footnotetext{
2 www.ecml.at
} 
na vysokých školách. Ta se orientuje na osvojení specifické odborné terminologie, důležité pro následnou praxi absolventů. Kromě toho je jazyková úroveň vysokoškolských studentů obvykle vyšší, než předpokládají běžně užívané online aplikace, určené pro širokou veřejnost. $Z$ tohoto důvodu preferují vyučující odborného cizího jazyka $\mathrm{v}$ terciární sfére vytváření vlastních výukových a testovacích materiálů. K tomuto účelu jsou vhodné aplikace umožňující tvorbu a následné sdílení vlastních interaktivních cvičení i multimediálních výukových modelů, např. LearningApps.org. Mezi studenty i vyučujícími jsou také oblíbené testovací online nástroje Quizlet a Kahoot!, jejichž atraktivita spočívá v synchronním zapojení všech př́tomných do testování realizovaného formou hry a v bezprostředním odhalení správné odpovědi i vyhodnocení pořadí jednotlivých aktérů. Nutno podotknout, že vytváření a sdílení online výukových materiálů předpokládá odpovídající mediální kompetenci pedagogů, kteř́ jsou v této oblasti často samouky, odkázanými na vlastní invenci. Nabídka kurzů a školení zaměřených na integraci digitálních technologií do výuky cizího jazyka je prozatím bohužel velmi omezená.

\section{Poslech}

Praxe ukázala, že m-learning je možné využívat nejen při osvojování gramatiky a slovní zásoby, ale také při procvičování jednotlivých řečových kompetencí: poslech, čtení, mluvení a psaní. Z výzkumů v oblasti neurofyziologie vyplývá, že tyto řečové dovednosti stojí ve vzájemném vztahu a podporují se (Heyd, 1997, s. 181), proto je nelze osvojovat a procvičovat zcela izolovaně. Dovednost poslech s porozuměním je klíčový element pro úspěšnou akvizici cílového jazyka. Díky porozumění mluvenému slovu se posluchač dokáže orientovat $v$ jazykové interakci, je schopen vytvářet a interpretovat vlastní názor a podílet se na diskuzi, v souladu s požadavky vysokoškolského vzdělávání pak na diskuzi v rámci studovaného oboru. $\mathrm{Z}$ tohoto důvodu by měl být $\mathrm{v}$ rámci osvojování cizího jazyka věnován poslechu s porozuměním náležitý prostor. Autoři moderních jazykových př́ruček jsou si významu poslechu vědomi a vybavují učebnice odpovídajícím množstvím poslechových cvičení. Jinak je tomu ovšem v terciárním vzdělávání, kde výuka odborného cizího jazyka probíhá pomocí skript a dalších, vyučujícím vypracovaných studijních materiálů, které obvykle neobsahují explicitní poslechová cvičení. Proto je za účelem nácviku selektivního, globálního a detailního porozumění mluvenému projevu nezbytné využívat jiné vhodné zdroje. A právě v tomto ohledu je m-learning důležitým nástrojem. Pro nácvik poslechu s porozuměním jsou v první řadě vhodné nejrůznější podcasty. Audiopodcasty ve formátu MP3 a videopodcasty ve formátu MP4 se v posledních letech staly neodmyslitelnou součástí mediálního prostředí. Na internetu najdeme široké spektrum podcastů z různých oblastí, tematicky vhodných pro výuku zaměřenou na odbornou praxi. Největší přednost podcastů spočívá v individualizaci poslechu, proto jsou doporučované zejména pro ř́zené samostudium, lze je ale také zakomponovat do prezenční fáze výuky. 
Zatímco na stránkách většiny zahraničních rozhlasových a televizních stanic (např. CNN, BBC, ARD, ZDF atd.) najdeme zejména nedidaktizované podcasty, nabízejí některá media a jazykové instituty didaktizované podcasty, které jsou doplněny přepisem textu a celou řadou cvičení. Patří $\mathrm{k}$ nim např. British Council (Listen and Watch), BBC Czech (Takeaway Business English), Daily ESL (Education and Work), Deutsche Welle (Langsam gesprochene Nachrichten), Goethe Institut (Deutsch am Arbeitsplatz) atd. Kromě výše uvedených profesionálně zpracovaných podcastů je nevyčerpatelným zdrojem adaptovaných i nedidaktizovaných podcastů, výukových videí a vlastních pořadů platforma YouTube.

\section{Čtení}

Čtení s porozuměním je vedle poslechu s porozuměním druhým nejdůležitějším zdrojem jazykového inputu, $\mathrm{v}$ tomto př́padě osvojovaného prostřednictvím textu jako vizuálního kanálu. Čtení poskytuje optimální př́ležitost zpracovat cílový jazyk individuálním tempem a uložit ho v dlouhodobé paměti. Stejně jako při výuce v mateřském jazyce se i v cizím jazyce studující seznamují s různými druhy textů a procvičují tak globální, selektivní a detailní porozumění. Protože tištěné studijní materiály mají obsahově omezenou kapacitu a navíc rychle ztrácí na aktuálnosti, je významným zdrojem vhodných autentických textů internet. Studující na vysokých školách využívají pro internetovou rešerši a následné čtení odborně zaměřených cizojazyčných textů obvykle smartphone nebo tablet, které umožnují flexibilní př́stup do databází, obsahujících nedidaktizované i didaktizované články s odbornou tematikou. Z časových důvodů jsou v prezenční fázi výuky upřednostňovány kratší texty, čtení delších textů je v rámci procvičování dané kompetence zpravidla součástí domácího řízeného samostudia. Nejrozšířenějším typem elektronických textů jsou nedidaktizované články. Najdeme je v online médiích (noviny, časopisy, webové stránky rozhlasových a televizních stanic), na webových stránkách podniků a firem, v naučných portálech, reklamách či inzerátech. Didaktizovaných textů je méně, o to jsou ale při osvojování jazyka významnější. Adaptované texty s porozuměním nabízí webové stránky nakladatelství cizojazyčných učebnic a jazykových institutů i některých veřejnoprávních rozhlasových a televizních společností, určených pro vysílání do zahraničí (viz kapitola Poslech). Didaktizované texty jsou také často koncipovány jako doprovodný materiál k zakoupené učebnici, nebo mohou být zpracovány vyučujícím příslušného předmětu a studujícím nasdíleny prostřednictvím MS Teams, SharePoint, OneDrive, Moodle, pomocí vlastního univerzitního informačního systému nebo některé profesionální webové aplikace, např́klad LearningApps.org.

\section{Psaní}

Dovednost psaní má ve výuce dvě základní funkce: prostředek a cíl. Psaní jako prostředek podporuje osvojování dalších základních dovedností (např. gramatiku 
a slovní zásobu) a zároveň je psaní samo o sobě důležitou cílovou kompetencí. Studující musí umět koncipovat písemný projev tak, aby srozumitelně a formálně korektně zprostředkoval obsah sdělení. $\mathrm{K}$ tomu je potřeba správně strukturovat text, propojit obsah, použít odpovídající jazykové prostředky a zohlednit specifické znaky př́slušného druhu textu i úzus v kultuře cílového jazyka (Janíková, 2015, s. 91). O psaní rukou je známo, že podporuje grafomotorické dovednosti a pamět' (Kast, 1999, s. 21) Otázkou je, co podporuje psaní na mobilních př́istrojích, které se vyznačují drobným displejem a malou klávesnicí, a bezpochyby proto nejsou způsobilé k produkci delších textů. Podle Mitchiana přesto skýtá psaní na virtuální klávesnici jisté výhody, protože je alternativou při procvičovacích aktivitách a paušálně funguje jako podpůrný element při učení. Proces psaní zároveň podporuje pozornost zaměřenou na objekt učení (Mitchian, 2010, s. 146).

Účelné jsou zejména takové nástroje a aplikace určené k procvičování gramatiky a slovní zásoby, kde musí studující sám doplnit př́slušný výraz, slovní spojení nebo celé věty. Na webových stránkách European Centre for Modern Languages of the Council of Europe je k dispozici seznam autorských nástrojů a aplikací, které umožňují procvičovat psaní pomocí m-learningu. Seznam zahrnuje širokou škálu nástrojů, od myšlenkových map přes vytváření prezentací až po psaní blogů a celých př́běhů. Přestože má dovednost psaní ve výuce odborného jazyka na vysokých školách pevné místo, doporučuje se s ohledem na nízkou hodinovou dotaci procvičovat tuto kompetenci $\mathrm{v}$ rámci řízeného samostudia, tedy mimo prezenční výuku.

\section{Mluvení}

Protože pro výuku cizího jazyka je ve srovnání s odbornými předměty charakteristický větší podíl bezprostřední sociální interakce, je věnován rozvoji dovednosti monologického a dialogického ústního projevu zvláštní zřetel. Na rozdíl od ostatních řečových dovedností je mluvení kompetencí nejméně vhodnou k samostudiu, proto by se mělo intenzivně podporovat především v prezenční fázi výuky. Za účelem rozvíjení řečové produkce s využitím m-learningu se nabízejí zejména následující aktivity:

- Mluvení na základě vizuálního podnětu (grafy, statistiky, fotky, obrázky, krátká videa)

- Internetové rešerše zaměřené na konkrétní úkol (prezentace výsledku, výměna informací)

- Reprodukce odborného textu

Během kooperační fáze výuky probíhá interakce ideálně v tandemu či menší skupině studujících, aby byli všichni účastníci komunikačně aktivní. Digitální technologie umožňují podporu řečové produkce i v rámci řízeného samostudia, kdy 
studující zaznamená monologický projev pomocí některé k tomu určené aplikace. Záznam lze poté využít jako nástroj autoevaluace, což znamená, že studující sám analyzuje svoji výslovnost, plynulost projevu i případné lexikální a gramatické chyby. Zároveň může záznam nasdílet svému vyučujícímu, který mu poté poskytne zpětnou vazbu. Příkladem aplikace umožňující nahrávání a sdílení mluveného projevu je VoiceThread.

Tab. 1: Konkrétni scénář tematického bloku s využitím m-learningu

\begin{tabular}{|c|c|c|}
\hline $\begin{array}{l}\text { Studijní forma } \\
\text { Subtéma }\end{array}$ & $\begin{array}{l}\text { M-learning v rámci hybridní výuky } \\
\text { Téma: žádost o pracovní místo }\end{array}$ & $\begin{array}{l}\text { Podporovaná } \\
\text { jazyková } \\
\text { kompetence }\end{array}$ \\
\hline $\begin{array}{l}\text { Hledání pracovního } \\
\text { místa }\end{array}$ & $\begin{array}{l}\text { Procvičování slovní zásoby k danému tématu pomocí interaktivních } \\
\text { cvičení na LearningApps.org apod. } \\
\text { Najít na internetu vhodný inzerát s nabídkou pracovního místa } \\
\text { a elektronicky ho uložit pro potřeby výuky. }\end{array}$ & $\begin{array}{l}\text { Slovní } \\
\text { zásoba } \\
\text { Čtení }\end{array}$ \\
\hline $\begin{array}{l}\text { Prezenční fáze } \\
\text { Inzerát prac. místa } \\
\text { Výběrové řízení }\end{array}$ & $\begin{array}{l}\text { Ve dvojici nebo menší skupině vzájemně prezentovat a porovnat } \\
\text { vybrané pracovní místo včetně požadavků na kandidáta a nabídky ze } \\
\text { strany zaměstnavatele. } \\
\text { Pomocí některé z digitálních Mindmap-aplikací strukturovat } \\
\text { a vizualizovat jednotlivé fáze a náležitosti výběrového řízení (práce } \\
\text { ve dvojici). }\end{array}$ & $\begin{array}{l}\text { Mluvení } \\
\text { Slovní } \\
\text { zásoba } \\
\text { Psaní }\end{array}$ \\
\hline Zaměstnavatel & $\begin{array}{l}\text { Rešerší na internetu získat informace o podniku z vybraného } \\
\text { inzerátu a jeho produktů. } \\
\text { Najít rozhlasovou nebo televizní reklamu na zmíněný produkt } \\
\text { a poslechnout si ji, případně najít audio či video prezentaci daného } \\
\text { podniku. }\end{array}$ & $\begin{array}{l}\text { Čtení } \\
\text { Poslech }\end{array}$ \\
\hline $\begin{array}{l}\text { Žádost o pracovní } \\
\text { pozici }\end{array}$ & $\begin{array}{l}\text { Prezentovat výsledky internetové rešerše, tj. nejdůležitější data } \\
\text { o podniku/zaměstnavateli (práce ve dvojici či menší skupině). } \\
\text { Najít na internetu tipy pro vytvoření úspěšné žádosti o pracovní } \\
\text { místo. }\end{array}$ & $\begin{array}{l}\text { Mluvení } \\
\text { Čtení }\end{array}$ \\
\hline $\begin{array}{l}\text { Samostudium } \\
\text { Motivační dopis, } \\
\text { životopis }\end{array}$ & $\begin{array}{l}\text { Pomocí př́slušné aplikace Bewerbungs-App, Cover Letter App } \\
\text { vytvořit aktraktivní a originální žádost o zaměstnání a zaslat ji } \\
\text { vyučujícímu ke kontrole, případně vytvořit životopis, např. pomocí } \\
\text { Lebenslauf-App, CV App, Resume Help. }\end{array}$ & Psaní \\
\hline $\begin{array}{l}\text { Prezenční fáze } \\
\text { Pracovní pohovor }\end{array}$ & $\begin{array}{l}\text { Najít na internetu tipy pro úspěšný pracovní pohovor. } \\
\text { Vyměnit si s kolegou nalezené tipy a vytvořit seznam doporučení } \\
\text { pro úspěšný pracovní pohovor. }\end{array}$ & $\begin{array}{l}\text { Čtení } \\
\text { Mluvení } \\
\text { Psaní }\end{array}$ \\
\hline $\begin{array}{l}\text { Samostudium } \\
\text { Pracovni pohovor }\end{array}$ & $\begin{array}{l}\text { Podívat se na video k tématu pracovní pohovor (YouTube, Goethe } \\
\text { Institut atd.), vypsat a formulovat nejdůležitější otázky. }\end{array}$ & $\begin{array}{l}\text { Poslech } \\
\text { Psaní }\end{array}$ \\
\hline $\begin{array}{l}\text { Prezenčnífáze } \\
\text { Shrnutí }\end{array}$ & $\begin{array}{l}\text { Pomocí aplikace Kahoot! prověřit zvládnutí tématu a relevantní } \\
\text { slovní zásoby. }\end{array}$ & $\begin{array}{l}\text { Slovní } \\
\text { zásoba }\end{array}$ \\
\hline
\end{tabular}




\section{Konkrétní scénář v rámci hybridní výuky}

Vhodnou kombinací výše nastíněných nástrojů m-learningu lze pro každé téma cizího, ekonomicky zaměřeného jazyka sestavit takový scénář výuky, který rovnoměrně podporuje jednotlivé řečové dovednosti a zároveň reflektuje požadavky hybridního konceptu výuky, rozděleného na prezenční, tj. kooperativní fázi výuky a řízené samostudium. $V$ následující tabulce jsou prezentovány jednotlivé fáze výuky na téma Žádost o pracovní místo. U každé jednotlivé aktivity je uvedeno, kterou konkrétní jazykovou kompetenci podporuje. Posledním bodem scénáře tematického bloku je testovací fáze, která prověřuje, jak si studující osvojili odborné znalosti i slovní zásobu.

Tab. 2: Př́klady vhodných ICT nástrojů pro výuku ekonomického jazyka na vysokých školách

\begin{tabular}{|c|c|c|c|c|}
\hline Gramatika & Slovní zásoba & \multicolumn{2}{|c|}{$\begin{array}{l}\text { Platforma pro vytváření } \\
\text { a sdílení digitálních materiálů }\end{array}$} & Testování \\
\hline $\begin{array}{l}\text { - DuoLingo } \\
\text { - Lingolia } \\
\text { - German Grammar Test* } \\
\text { - Grammar Test** }\end{array}$ & $\begin{array}{l}\text { - Memorize Now } \\
\text { - Anki } \\
\text { - Landigo } \\
\text { - Dril }\end{array}$ & \multicolumn{2}{|l|}{$\begin{array}{l}\text { - LearningApps } \\
\text { - Tes teach } \\
\text { - Nearpod } \\
\text { - Padlet }\end{array}$} & $\begin{array}{l}\text { - Kahoot! } \\
\text { - Quizlet } \\
\text { - Hot Potatoes }\end{array}$ \\
\hline Poslech & Čtení & Psaní & Mluvení & Výslovnost \\
\hline $\begin{array}{l}\text { - Juice } \\
\text { - Tuneln } \\
\text { - Learn German DW* } \\
\text { - Goethe Institut* } \\
\text { - British Council** }\end{array}$ & $\begin{array}{l}\text { - Mendeley } \\
\text { - Learn German DW* } \\
\text { - Nachrichten leicht* } \\
\text {-Business magazine** } \\
\text { (web British Council) }\end{array}$ & $\begin{array}{l}\text { - Lang-8 } \\
\text { - Mindmeister } \\
\text { - Prezi } \\
\text { - Google Docs }\end{array}$ & $\begin{array}{l}\text { - Audacity } \\
\text {-VoiceThread } \\
\text { - Lingt }\end{array}$ & $\begin{array}{l}\text { - Forvo } \\
\text { - Rhinospike }\end{array}$ \\
\hline
\end{tabular}

\section{Závěr}

Rozšíření mobilních digitálních přístrojů přináší do výuky odborného cizího jazyka na vysokých školách nové perspektivy, díky kterým se m-learning profiluje jako účinný nástroj při akvizici produktivních a receptivních kompetencí, a to jak $\mathrm{v}$ prezenční fázi výuky, tak i v rámci ř́zeného samostudia. Využití smartphonu při výuce ekonomického jazyka by se nemělo omezovat pouze na nástroje a aplikace vhodné pro osvojování slovní zásoby a procvičování gramatiky, ale s ohledem na rovnoměrný rozvoj všech řečových dovedností by mělo zahrnovat pestrou škálu funkcí a možností, které moderní mobilní přístroje připojené $\mathrm{k}$ internetu nabízejí, včetně autorských webových nástrojů k vytváření a sdílení online výukových materiálů.

\section{Literatura}

BiEbighäUSER, K. (2015). DaF-Lernen mit Apps. Zur Einleitung der Sondernummer. GFL-Journal 2015 (2), 1-14. [online]. Dostupné z: http://www.gfl-journal.de/2-2015/biebighaeuser.pdf [cit. 25. 1. 2020].

Brunner, R. (2014). Potenziale von Mobile Learning mit Smartphones in der Sekundarstufe I. Master Thesis zur Erlangung des akademischen Grades Master of Arts (M. A.) [online]. Dostupné z: http:// 
www.ptsleonding.at/images/documents/Startseite_News/brunner_regina_endfassung_T 15032014_PRINT.pdf [cit. 05. 2. 2019].

HATTIE, J. A. C. (2009). Visible Learning. A synthesis of over 800 meta-analyses relating to achievement. London \& New York: Routledge.

HEYD, G. (1997). Aufbauwissen für den Fremdsprachenunterricht (DaF). Tübingen: Gunter Narr Verlag.

JANíkovÁ, V. (2015). Didaktik des Unterrichts Deutsch als Fremdsprache. Eine Einführung. Brno: Masarykova univerzita.

KAST, B. (1999). Fertigkeit Schreiben. München: Langenscheidt.

Mitschian, H. (2010). Mobiles Lernen für Deutsch als Fremdsprache. M-Learning - die neue Welle? Kassel: Kassel University Press.

MobilMania.cz: Smartphone používá 96 \% českých studentů, chrání jej však méně než polovina. [online]. Dostupné z https://www.mobilmania.cz/clanky/smartphone-pouziva-96\%20ceskych-studentu -chrani-jej-\%20vsak-\%20mene-\%20nez-polovina/sc-3-a-1343136/default.aspx [cit. 01. 2. 2020].

PFEIL, A. (2015). Digitale und analoge Lernwelten im Deutsch als Fremdsprache-Unterrricht. Fremdsprache Deutsch. Zeitschrift für die Praxis des Deutschunterrichts 2015 (53), 3-7.

\section{Autorka}

PhDr. Lenka Kalousková, Ph.D., Katedra německého jazyka, Fakulta mezinárodních vztahů, VŠE Praha, e-mail: lenka.kalouskova@vse.cz

Absolventka germanistiky a historie na Filozofické fakultě Univerzity Karlovy (UK) se semestrálními pobyty na univerzitách v Lipsku a v Bernu. Doktorát získala na UK z německé filologie. Od roku 1999 působí na Katedře německého jazyka Vysoké školy ekonomické v Praze, kde se zaměřuje na výuku ekonomické němčiny. K tématům, kterým se věnuje, patří např. lingvodidaktické aspekty profesního jazyka pro hospodářskou sféru, práce s chybou ve výuce cizího jazyka, mediální didaktika (m-learning) a onomastika. Pravidelně publikuje v tuzemských i zahraničních časopisech. 